\title{
Incidental Discovery of Sphenoid Sinuses Agenesis: A Report of Two Cases in Benin, West Africa
}

\author{
Djivèdé Akanni1,2*, Charles Agossou ${ }^{3,4}$, Eulalie Sansuamou ${ }^{3,4}$, Fatiou Bouraïma1,5, \\ Patricia Yèkpè̀ ${ }^{3,4}$, Kofi-Mensa Savi de Tovè ${ }^{1,2}$, Olivier Biaou ${ }^{3,4}$, Vicentia Boco ${ }^{3,4}$ \\ ${ }^{1}$ Faculty of Medicine, University of Parakou, Parakou, Benin \\ ${ }^{2}$ Department of Radiology, University Teaching Hospital of Borgou Department, Parakou, Benin \\ ${ }^{3}$ Faculty of Health Sciences, University of Abomey Calavi, Cotonou, Benin \\ ${ }^{4}$ Department of Radiology, National and University Teaching Hospital Hubert Koutoukou Maga, Cotonou, Benin \\ ${ }^{5}$ Department of Otorhinolaryngology, University Teaching Hospital of Borgou Department, Parakou, Benin \\ Email: ^djivakanni@yahoo.fr
}

How to cite this paper: Akanni, D. Agossou, C., Sansuamou, E., Bouraïma, F., Yèkpè, P., de Tovè, K.-M.S., Biaou, O. and Boco, V. (2019) Incidental Discovery of Sphenoid Sinuses Agenesis: A Report of Two Cases in Benin, West Africa. Advances in Molecular Imaging, 9, 1-5.

https://doi.org/10.4236/ami.2019.91001

Received: September 24, 2018

Accepted: December 4, 2018

Published: December 7, 2018

Copyright $\odot 2019$ by authors and Scientific Research Publishing Inc. This work is licensed under the Creative Commons Attribution International License (CC BY 4.0).

http://creativecommons.org/licenses/by/4.0/

\begin{abstract}
Sphenoid sinuses are carved into the body of the sphenoid bone. They are probably the most variably pneumatized structures of the skull. They begin their pneumatization at the age of three and finished at adolescence. Several anatomic variants of sphenoid sinuses have been described in the literature. The agenesis of sphenoid sinuses in adults is very rarely found. We report two incidental cases of sphenoid sinuses agenesis discovered on CT scan in Benin, West Africa.
\end{abstract}

\section{Keywords}

Sphenoid, Agenesis, CT-Scan, Benin

\section{Introduction}

Sphenoid sinuses are irregular cavities dug in the body of the sphenoid. They have been described as the most variable cavities of the human body [1]. They are surrounded by vital neurovascular structures such as internal carotid arteries, optic nerves, cavernous sinuses, maxillary and vidian nerves. The degree of pneumatization of sphenoidal sinuses varies from absence to extension of this pneumatization to adjacent structures such as anterior clinoid processes, pterygoid processes, and great wings [2] [3]. Agenesis of sphenoidal sinuses is rare, except in cases of cranio-facial malformations [4]. The endoscopic endonasal approach of the pituitary gland is now the gold standard of pituitary gland 
surgery. Agenesis of sphenoid sinuses increases the surgical difficulty of the endoscopic endonasal approach of the pituitary gland. We present two consecutive cases of bilateral agenesis sphenoidal sinuses fortuitously discovered by using Computed Tomography (CT-scan) in the Radiology Department of the National and University Teaching Hospital Hubert Koutoukou Maga of Cotonou in Benin (CNHU/HKM).

\section{Observations}

\subsection{Case 1}

Young woman, 33 years old, with no particular medical antecedent, in whom a CT skull scan was requested in the context of head trauma on June 15, 2016. Computed tomographic scanning was performed in the Radiology Department of the CNHU / HKM on EMOTION SIEMENS 16 slices. No traumatic lesions were found, including no bleeding or fracture. But there was an absence pneumatization of the sphenoid sinuses (Figure 1) and the right frontal sinus (Figure 2).

\subsection{Case 2}

A 66-year-old woman with a history of high blood pressure was received in the

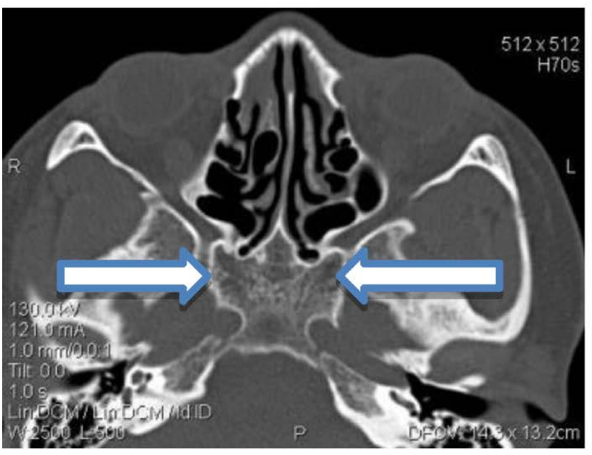

(a)

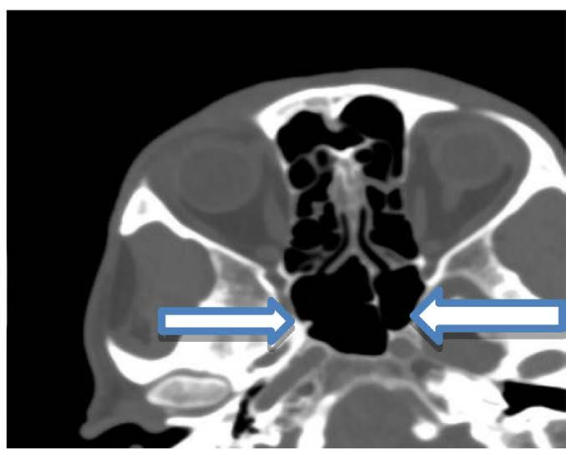

(b)

Figure 1. CT in bone window in axial cuts shows comparison of case 1 (a): agenesis of sphenoid sinuses and (b) normal pneumatization of sphenoid sinuses (arrows).

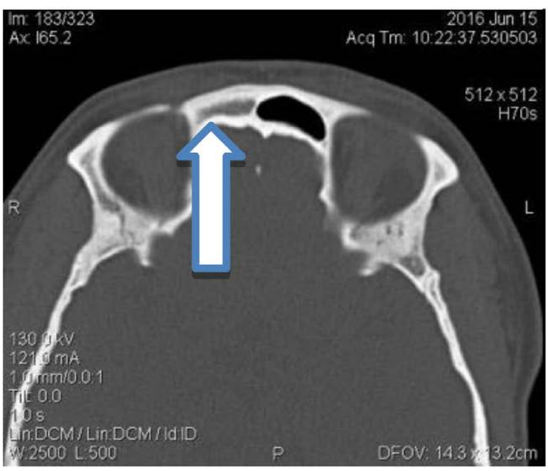

(a)

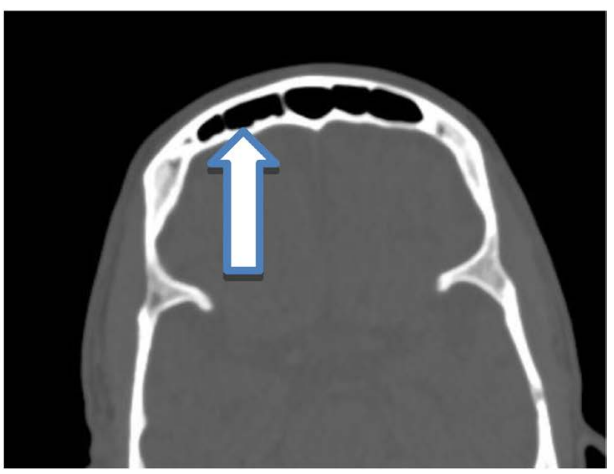

(b)

Figure 2. CT in bone window in axial cuts shows comparison of case 1 (a): agenesis of right frontal sinus and (b) normal pneumatization of right frontal sinus (arrow). 


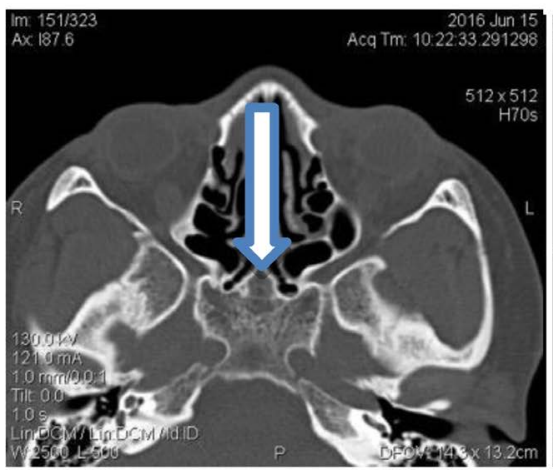

(a)

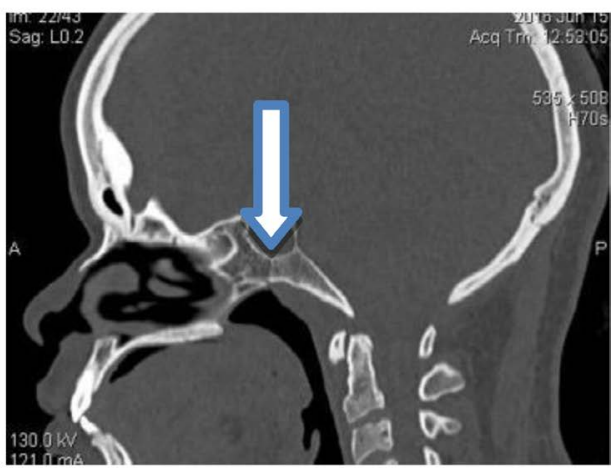

(b)

Figure 3. CT in bone window, axial (a) cut and sagittal reconstruction (b) showing absence of pneumatization of the body of the sphenoid (arrow).

Table 1. Sociodemographic and clinical characteristics of two cases.

\begin{tabular}{ccccc}
\hline & Sex & Age & Clinical characteristics & CT scan skull findings \\
\hline Case 1 & Female & 33 & Head trauma & $\begin{array}{c}\text { No bleeding, no fracture } \\
\text { Agenesis of sphenoid sinuses and right } \\
\text { frontal sinus }\end{array}$ \\
Case 2 & Female & 66 & Stroke & $\begin{array}{c}\text { Ischemic stroke of the territory of the } \\
\text { right posterior artery } \\
\text { Agenesis of sphenoid sinuses }\end{array}$ \\
\hline
\end{tabular}

Radiology Department of CNHU/HKM on June 25, 2016; for the exploration of a left hemi-corporeal deficit. Computed tomographic examination revealed an ischemic stroke of the territory of the right posterior artery. The visualization of the bone window found an absence of the pneumatisation of the sphenoid sinuses (Figure 3). Table 1 summarizes the sociodemographic and clinical characteristic of two cases.

\section{Discussion}

The body of the sphenoid bone is hollowed out in its interior to form two large cavities, the sphenoid sinuses. The spaces occupied by sphenoid sinuses largely vary. These cavities are asymmetrical irregular. The sphenoid sinuses are absent at birth. Their pneumatization begins around three years old, but they reach their maximal size only at adolescence [1] [5] [6].

Depending on the degree of pneumatization of the sphenoid sinuses, there are three main types: the conchal type, the presellar type and the sellar type [6]. Conchal type pneumatization is a vestigial pneumatization, where aeration of the sinuses is limited to the rostral part of the sphenoid bone. The prevalence of this type of pneumatization varies from $0 \%$ to $28 \%$, according to the literature [3] [6]. In Benin conchal type was found in 0.4\% [7]. Presellar pneumatization is where sinus aeration does not extend beyond the vertical line through tuberculum sellae [4] [8]. This type of pneumatization is found in proportions varying from $2 \%$ to $42 \%$, according to literature [3] [8]. The presellar type was found in 
$24.9 \%$ of studied samples in Benin [7]. Sellar type pneumatization is where sinus aeration extends beyond tuberculum sellae [4] [6]. This type of pneumatization is the most common and found between $14 \%$ and $98 \%$ of cases in the literature [3] [8]. In Benin, sellar type pneumatization was observed in $74.7 \%$ of cases [7]. Bilateral agenesis of sphenoid sinuses has rarely been described, particularly in CT [9] [10] [11]. We do not see the description of the bilateral agenesis of sphenoid sinuses among black people in the literature. In 2008, Sonbay et al. [12] in their study of 1193 Skull CT-scan examined over a ten-year period on Turkish, found only eight cases $(0.65 \%)$ of sphenoid sinuses agenesis, of which only three cases of bilateral agenesis. It is the first that the bilateral agenesis of sphenoid sinuses is described in Benin in two black patients.

Agenesis of the sphenoid sinuses seems to be more frequent in female subjects [4] [9] [10] [11] as in our patients. Agenesis is also more common in cases of craniosynostosis, osteodysplasia or as part of a cranio-facial malformation disease such as Hand-Schuller-Christian disease [4] [9] [10] [11]. Isolated agenesis of the sphenoid sinuses without craniofacial dysmorphia is extremely rare [12]. Our two cases had no craniofacial dysmorphia.

Sometimes, pneumatization of the sphenoid sinuses extends to adjacent structures such as anterior clinoid processes, pterygoid processes, lesser and great wings of the sphenoid [13]. The greater the pneumatization of sinuses is, the more neurovascular structures burst into sinuses [14].

When they are well pneumatized, sphenoid sinuses are a preferred route of choice for surgery in the sellar region [15]. In case of agenesis of the sphenoid sinuses, there is difficulty for the direct trans-sphenoidal approach. But, in the absence of the pneumatization of the sphenoid sinuses, the pneumatization of adjacent structures could be alternative surgical routes.

In our two patients, there was no pneumatization of the adjacent structures of sphenoid sinuses. In this case, the surgeon needs to mill the middle part of the sphenoid body [15].

It is therefore important to specify clearly the type of pneumatisation of the sphenoid sinuses by using CT scan before any endonasal surgery [15].

\section{Conclusion}

Agenesis of sphenoid sinuses documented using CT among Black African is extremely rare. The more use of CT in head and neck pathology will increase this rate in Black African country.

\section{Conflicts of Interest}

The authors have no conflict of interest to declare

\section{Authors Contributions}

Akanni D conceived the study. Agossou C and Sansuamou E collected the data. Akanni D drafted the manuscript. All authors approved the final version of the article. 


\section{References}

[1] Casselman, J.W. (2003) The Sphenoid Bone: Anatomy. Journal of Neuroradiology, 30, 201-210.

[2] Anusha, B., Baharudin, A., Philip, R., Harvider, S. and Shaffie, B.M. (2014) Anatomical Variations of the Sphenoid Sinus and Its Adjacent Structures: A Review of Existing Literature. Surgical and Radiologic Anatomy, 36, 419-427.

https://doi.org/10.1007/s00276-013-1214-1

[3] Lupascu, M., Comsa, G.I. and Zainea, V. (2014) Anatomical Variations of the Sphenoid Sinus-A Study of 200 Cases. ARS Medica Tomitana, 20, 57-62.

https://doi.org/10.2478/arsm-2014-0011

[4] Keskin, G., Üstündag, E. and Citfci, E. (2002) Agenesis of Sphenoid Sinuses. Surgical and Radiologic Anatomy, 24, 324-326. https://doi.org/10.1007/s00276-002-0028-3

[5] Hammer, G. and Radberg, C. (1961) The Sphenoidal Sinus: An Anatomical and Roentgenologic Study with Reference to Transsphenoid Hypophysectomy. Acta Radiologica, Original Series, 56, 401-422. https://doi.org/10.1177/028418516105600601

[6] Lokwani, M.S., Patidar, J. and Parihar, V. (2018) Anatomical Variations of Sphenoid Sinus on Multi-Detector Computed Tomography and Its Usefulness in Trans-Sphenoidal Endoscopic Skull Base Surgery. International Journal of Research in Medical Sciences, 6, 3063. https://doi.org/10.18203/2320-6012.ijrms20183645

[7] Yèkpè, P., Akanni, D., de Souza, C.O., Adjadohoun, S., Kiki, M., de Tovè, K.-M.S., Biaou, O. and Boco, V. (2018) Anatomic Variants of Sphenoid Sinuses and Adjacent Structures: A Study of 225 Skull CT Scans at CNHU-HKM in Benin, West Africa. Open Journal of Radiology, 8, 181-190. https://doi.org/10.4236/ojrad.2018.83021

[8] Budu, V., Mogoantă, C.A., Fănuță, B. and Bulescu, I. (2013) The Anatomical Relations of the Sphenoid Sinus and Their Implications in Sphenoid Endoscopic Surgery. Romanian Journal of Morphology and Embryology = Revue Roumaine de Morphologie et Embryologie, 54, 13-16.

[9] Anik, I., Anik, Y., Koc, K. and Ceylan, S. (2005) Agenesis of Sphenoid Sinuses. Clinical Anatomy (New York, N.Y.), 18, 217-219. https://doi.org/10.1002/ca.20096

[10] Orhan, M., Govsa, F. and Saylam, C. (2010) A Quite Rare Condition: Absence of Sphenoidal Sinuses. Surgical and Radiologic Anatomy, 32, 551-553. https://doi.org/10.1007/s00276-010-0623-7

[11] Baylançiçek, S. (2014) Sphenoid Sinus Agenesis. The Turkish Journal of Ear Nose and Throat, 24, 354-356. https://doi.org/10.5606/kbbihtisas.2014.56255

[12] Sonbay, D., Saka, C., Akin, I., Gunsoy, B. and Gokler, A. (2010) Prevalence of Sphenoid Sinus Agenesis in Adults: A CT Scan Study. B-ENT, 6, 167-169.

[13] Craiu, C., Sandulescu, M. and Rusu, M.C. (2015) Variations of Sphenoid Pneumatization: A CBCT Study. Romanian Journal of Rhinology, 5, 107-113. https://doi.org/10.1515/rjr-2015-0013

[14] Dal Secchi, M.M., Dolci, R.L.L., Teixeira, R. and Lazarini, P.R. (2018) An Analysis of Anatomic Variations of the Sphenoid Sinus and Its Relationship to the Internal Carotid Artery. International Archives of Otorhinolaryngology, 22, 161-166. https://doi.org/10.1055/s-0037-1607336

[15] Seddighi, A., Mellati, O., Ghorbani, J., Raad, N. and Soleimani, M.M. (2014) Sphenoid Sinus: Anatomic Variations and Their Importance in Trans-Sphenoid Surgery. International Clinical Neuroscience Journal. http://journals.sbmu.ac.ir/Neuroscience/article/view/6599 